Dariusz GRZYBEK

Uniwersytet Jagielloński

dg30@wp.pl

\title{
ŚWIATOPOGLĄD A NACJONALIZM W MYŚLI POLITYCZNEJ KAROLA LUDWIKA KONIŃSKIEGO
}

ABSTRACT Neoromantic worldview and idea of nationality in political thought of Karol Ludwik Koniński

This paper analyses concept of nationality in writings of Karol Ludwik Koniński (1891-1943), polish writer and literary critic. Koniński was exceptional religious thinker, considering idea of Almighty God rather like moral postulate than reality. His philosophical-theological thinking has many similarities to Simone Weil's thought. The main concept in Koniński's thought was distinction between 'worthwile living' and 'worthless living' inspired by neoromantic thinkers like Jean Marie Guyau, Otto Weininger and Stanisław Brzozowski. In his opinion the most worthy way of living was live in accordance with universal ethics and national culture, considered as moral heritage of past generations. Idea of nation bolstered by Koniński was idea of cultural community inspired by heroic work of national elites. In political context of his times Koniński recognized special task of Poland in propagation of idea political Liberty in East Europe, in his terms it was 'the Greatness of Poland'. However, he missed economic aspect of political power, in consequence his heroic idea of polish nationality become neoromantic utopia of will.

Key words: neoromanticism, christianity, nationalism, Poland, Karol Ludwik Koniński

Słowa kluczowe: neoromantyzm, chrześcijaństwo, nacjonalizm, Polska, Karol Ludwik Koniński 
K arol Ludwik Koniński (1891-1943) należy do myślicieli raczej słabo znanych szerszej publiczności, ale mających grono oddanych czytelników. Obecny jest on w kulturze polskiej głównie jako autor wydanych pośmiertnie zapisków zawierających rozważania na temat religii i fundamentalnych kwestii ludzkiej egzystencji: Nox atra, Ex labyrintho, Uwagi 1940-1942¹. Za życia Koniński bardziej znany był jako krytyk literacki i publicysta polityczny. Pisywał do licznych czasopism naukowych i literackich, jak „Przegląd Współczesny”, „Gazeta Literacka” czy „Prosto z Mostu”, „Zet” Jerzego Brauna, jak też do endeckiej „Myśli Narodowej”, katolickiego „Głosu Narodu”, a później pism związanych z umiarkowaną opozycją antysanacyjną ${ }^{2}$. Wydał także dwutomową antologię pt. Pisarze ludowi, którą opatrzył wstępem i komentarzami. Do klasyki polskiej nowelistyki weszła też jego nowela Straszny czwartek $w$ domu pastora z 1938 roku.

Koniński długo nie był członkiem żadnego ugrupowania politycznego, choć sympatyzował z Narodową Demokracją i Obozem Wielkiej Polski, pod koniec lat 30. zniechęcony do obozu narodowego związał się z tzw. Frontem Morges, a w 1938 roku oficjalnie wstąpił do Stronnictwa Pracy ${ }^{3}$. Jednak na wszystkich tych etapach jego publicystyka miała cechy indywidualne, czyniące z niej pewne odrębne zjawisko w dziejach polskiej myśli politycznej. Zmiany sympatii politycznych Konińskiego w mniejszym stopniu wynikały z ewolucji ideowej, a bardziej z osobistych rozczarowań. Już bowiem w latach 20. stanowisko ideowe Konińskiego sytuowało go poza głównym nurtem obozu narodowego, którego dalsza ewolucja była pisarzowi niemiła.

Wśród stabilnych elementów myśli Konińskiego umieścić należy jego koncepcję narodu. Była to idea narodu jako wspólnoty opartej na kulturze, powstałej i nieustannie podtrzymywanej dzięki pracy elit, niosących w sobie element heroizmu. Uczestnictwo w tym zbiorowym wysiłku kulturalnym miało nadawać sens jednostkowej egzystencji, która bez nieustannej pracy intelektualnej i moralnej zdawała się Konińskiemu pozbawiona znaczenia. W ujęciu Konińskiego jednostka sama musi konstruować wartości, nawet jeśli efektem tej pracy ma być uznanie, że te istnieją niezależnie od niej. W jego dziełach filozoficzno-religijnych człowiek „zdobywa Boga” i „buduje wiarę”. Autor $E x$ labyrintho pragnął oprzeć swą religijność na doświadczeniach egzystencjalnych, a czynił to pomimo istnienia gotowego systemu religijnego, jakim był katolicyzm, pozostający dlań obiektem niewątpliwej fascynacji.

Pojmowanie sensu egzystencji poprzez czynne uczestnictwo w kulturze wyraźnie wskazuje na inspiracje Konińskiego, którymi były prace Stanisława Brzozowskiego, obecny jest także wpływ pism Zygmunta Balickiego i Zygmunta Wasilewskiego, a prócz

K.L. Koniński, Nox atra, Warszawa 1961; tenże, Ex labyrintho, Warszawa 1962; tenże, Uwagi 1940-1942, oprac. B. Mamoń, Poznań 1987.

2 K. Wyka, Koniński Karol Ludwik, [w:] Polski stownik biograficzny, t. 13, Wrocław-Warszawa 1967-1968, s. 532-534; B. Mamoń, Karol Ludwik Koniński, Kraków 1969, s. 7-34, Ludzie i Czasy, 6.

3 B. Mamoń, Karol Ludwik Koniński, s. 56.

4 K.L. Koniński, Budowa wiary. Traktat teologiczny, [w:] tenże, Zagadnienia religijne. Szkice, oprac. i wstęp Ł. Front, Kraków 2010, s. 226-252, Pisma Wybrane. 
tego wielu myślicieli epoki modernizmu. Nieobce mu były dzieła Nietzschego, zwraca uwagę znajomość Jeana Marie Guyau i Ottona Weiningera, którzy najprawdopodobniej wpłynęli na jego koncepcję życia wartościowego.

Był więc Koniński kontynuatorem polskiego inteligenckiego radykalizmu z przełomu wieków ${ }^{5}$ Spośród różnych jego wersji najbardziej przejął się tą, która za ideał obrała służbę wspólnocie narodowej'. Doktryna polityczna narodowej demokracji, którą Koniński popierał, zawierała w sobie napięcie pomiędzy wzniosłością moralną, jaką wiązano z pojęciem narodu, a brutalnością realnej polityki, uznawaną za nieuniknioną konieczność. Sprzeczności te bywały maskowane za pomocą dość prostych formul, jak zastosowane przez Dmowskiego w Myślach nowoczesnego Polaka rozróżnienie na etykę chrześcijańską, obowiązującą w życiu prywatnym, i etykę narodową, obowiązującą w życiu publicznym 7 . Już w niepodległej Polsce Roman Rybarski, za Dmowskim, wyjaśniał, że stosowanie niemoralnych metod w polityce jest koniecznością, skoro stosują je także nasi przeciwnicy ${ }^{8}$ W publicystyce Konińskiego napięcie owo jest szczególnie silne, co wydaje się skutkiem jego pojmowania kondycji ludzkiej, którą postrzegał jako nieodwołalnie tragiczną.

Zrozumienie światopoglądu Karola Ludwika Konińskiego nie wydaje się możliwe bez znajomości jego późnych pism. Przełomowym wydarzeniem dla poznania twórczości Konińskiego było wydanie jego zapisków filozoficzno-religijnych Nox atra (1961) i Ex labyrintho (1962). Ich uzupełnieniem były Uwagi, osobliwy dziennik czasu wojny, odczytany z rękopisu i opracowany przez Bronisława Mamonia, wydany w roku 1987. Także Bronisław Mamoń był autorem pierwszej poświęconej Konińskiemu monografii, która ukazała się w 1969 roku. Książka ta pozostaje do dziś podstawową i najbardziej wszechstronną pracą o Konińskim. Autor oparł się nie tylko na publikowanych wówczas pismach autora Ex labyrintho, ale także na rękopisach, które znacznym nakładem pracy odczytał i przygotował do druku.

Jego lewicową odmianę najlepiej opisują prace Andrzeja Walickiego i Andrzeja Mencwela. Zob. A. Walicki, Stanistaw Brzozowski - drogi myśli, Warszawa 1977; tenże, Polska, Rosja, marksizm. Studia z dziejów marksizmu i jego recepcji, Warszawa 1983, Biblioteka Studiów nad Marksizmem, 24; A. Mencwel, Etos lewicy. Esej o narodzinach kulturalizmu polskiego, Warszawa 1990; tenże, Stanistaw Brzozowski. Postawa krytyczna. Wiek XX, Warszawa 2014, Seria Historyczna Wydawnictwa Krytyki Politycznej, 17.

6 Klasycznymi pracami na temat genezy i rozwoju myśli narodowo-demokratycznej są: R. Wapiński, Narodowa Demokracja 1893-1939. Ze studiów nad dziejami myśli nacjonalistycznej, Wrocław 1980; tenże, Roman Dmowski, Lublin 1988; T. Kulak, Jan Ludwik Poptawski - biografia polityczna, Wrocław 1994; B. Grott, Zygmunt Balicki. Ideolog Narodowej Demokracji, Kraków 1995; A. Dawidowicz, Zygmunt Balicki (1858-1916). Dziatacz i teoretyk polskiego nacjonalizmu, Kraków 2006. Interesującą interpretacją doktryny wczesnej endecji jako modernistycznego radykalizmu jest praca Grzegorza Krzywca Szowinizm po polsku. Przypadek Romana Dmowskiego (1886-1905), Warszawa 2009. Pewną jej wadą jest nieco chaotyczna konstrukcja, w tym nadmiar dygresji, oraz drobne pomyłki, przez co główna teza nie jest konsekwentnie przeprowadzona. Por. recenzję tej książki autorstwa B. Grotta w: „Politeja” 2010, nr 14, s. 621-626.

R. Dmowski, Myśli nowoczesnego Polaka, Lwów 1907, s. 230-232.

8 R. Rybarski, Naród, jednostka i klasa, Warszawa 1926, s. 177-184.

9 B. Mamoń, Karol Ludwik Koniński. 
W ostatnich latach pisma Konińskiego wzbudzają zainteresowanie badaczy literatury, czego owocem są między innymi monografie autorstwa Adama Kalbarczyka ${ }^{10}$ i Adama Fitasa ${ }^{11}$ oraz Łukasza Fronta ${ }^{12}$. Ostatnia z tych prac jest ambitną próbą rekonstrukcji całości światopoglądu Konińskiego, ukazującą jego myśl w kontekście katolickiego modernizmu, pomijającą jednak niektóre inne jej konteksty. Ukazały się także Pisma wybrane pod redakcją Adama Fitasa i Macieja Urbanowskiego, w czterech tomach zawierających: zapiski autobiograficzne $e^{13}$, prace krytycznoliterackie ${ }^{14}$, teksty poświęcone zagadnieniom religijnym ${ }^{15}$ oraz publicystykę polityczną ${ }^{16}$. Jak dotąd nie doszło do reedycji trzech wymienionych tomów rozważań filozoficzno-religijnych.

Kwestie poglądów politycznych Konińskiego były omawiane we wspomnianej książce Bronisława Mamonia oraz w szkicach autorstwa Rafała Łętochy ${ }^{17}$ i Tomasza Sikorskiego ${ }^{18}$ (niestety dwaj ostatni autorzy niezbyt uważnie czytali Konińskiego, błędnie przypisując mu „brak uprzedzeń”). Niniejszy artykuł analizuje rozumienie idei narodowej przez Konińskiego, przy wykorzystaniu zarówno międzywojennej publicystyki, jak i pism powstałych w czasie wojny. Pozwoli to lepiej zrozumieć jego poglądy polityczne, jak też zobaczyć ich miejsce w dziejach myśli polskiej.

\section{ANTROPOLOGIA EGZYSTENCJALNA I METAFIZYKA WYWIEDZIONA Z WARTOŚCI}

Opublikowane za życia pisma Konińskiego w ograniczonym stopniu zawierają treści obecne w jego tekstach powstałych w czasie wojny. Koniński jako autor Nox atra stawia najbardziej podstawowe pytania dotyczące życia ludzkiego, nie stroniąc od wyznań bardzo intymnych. Rozważania te nie pozostają jednak bez związku z jego publicystyką polityczną. Tak jak w pismach religijnych głównym problemem jest odpowiedzialność jednostki za własne życie, tak w pismach politycznych jest nim odpowiedzialność jednostki za społeczne skutki jej życia. Podobne jest też przekonanie, że twórcza jednostka

10 A. Kalbarczyk, Upodstaw krytyki. O aksjologii literackiej Karola Ludwika Konińskiego, Lublin 2001.

11 A. Fitas, Gtos z labiryntu. Opismach Karola Ludwika Koninskiego, Wrocław 2003, Monografie Fundacji na Rzecz Nauki Polskiej. Seria Humanistyczna.

12 Ł. Front, Myśl religijna polskiego modernizmu i jej konteksty (Karol Ludwik Koniński), Kraków 2014, Biblioteka Tradycji. Seria 2, 135.

13 K.L. Koniński, Kartki z brulionów, oprac. i wstęp B. Mamoń, Kraków 2007, Pisma Wybrane.

14 Tenże, Szkice krytyczne. Wybór, oprac. i wstęp A. Fitas, Kraków 2007, Pisma Wybrane.

15 Tenże, Zagadnienia religijne...

16 Tenże, Pisma polityczne, oprac. i wstęp M. Urbanowski, Kraków 2014, Pisma Wybrane.

17 R. Eętocha, Socjalizm chrześcijański Karola Ludwika Konińskiego, [w:] tenże, O dobro wspólne. Szkice z katolicyzmu spotecznego, Kraków 2010, s. 265-278.

18 T. Sikorski, Nacjonalizm humanistyczny - czyli patriotyzm wolny od uprzedzeń w pisarstwie politycznym i krytyce literackiej Karola Ludwika Konińskiego (1891-1943), [w:] Narodowa demokracja XIX-XXI wiek. Dzieje ruchu politycznego, t. 1: Koncepcje - ludzie, red. T. Sikorski, A. Wątor, Toruń 2012, s. $477-490$. 
musi walczyć o nadanie sensu własnemu życiu, zarówno kiedy idzie o pracę dla własnej wspólnoty, jak i pracę nad „budowaniem wiary”. Stąd późniejsze prace Konińskiego zdają się rzucać światło na jego wcześniejsze teksty. Koncepcja człowieczeństwa zawarta w trylogii Nox atra, Ex labyrintho, Uwagi wydaje się spójna z antropologią wcześniejszych tekstów Konińskiego, z kolei koncepcja narodu z tych ostatnich nie została w jego późnych pismach zakwestionowana ${ }^{19}$. Stąd też analiza politycznych wypowiedzi autora Ex labyrintho wymaga przedstawienia jego antropologii, która ujawnia się głównie w jego dziełach religijnych.

Specyfika Konińskiego jako pisarza religijnego polega na tym, że nie przyjmował on religii objawionej jako bezwzględnej prawdy, a jednocześnie chrześcijaństwo, i to w konkretnej postaci katolicyzmu, stanowiło dla niego główny punkt odniesienia. Z doktryny katolickiej brał on wyobrażenie Boga, którego „zdobywanie” okazywało się najważniejszą kwestią ludzkiej egzystencji, zarazem nie był on w stanie przyjąć bez dyskusji podstawowych elementów katolickiej ortodoksji. Bóg u Konińskiego jest postulatem sumienia, jest moralną koniecznością, jednak jego istnienie faktyczne nie jest pewne. Postawa taka jest rzadko otwarcie wyrażana w myśli polskiej, w świecie idei najbliższa Konińskiemu wydaje się Simone Weil. Francuska myślicielka pozostała zafascynowana chrześcijaństwem, zbliżała się do przyjęcia katolicyzmu, w różnych religiach i filozofiach poszukiwała intuicji chrześcijańskich, a jednak nigdy nie zdecydowała się ochrzcić $^{20}$. Różni ich kwestia stylu: sposób pisania Weil był niezwykle zwięzły i aforystyczny, Koniński natomiast używał wielu sformułowań patetycznych i ekspresyjnych. Pisma Weil zdradzają także większą erudycję filozoficzną, podczas gdy autor Nox atra był przede wszystkim literatem. Mimo stylistycznej dyscypliny rozważania Weil zawierają więcej paradoksów, podczas gdy ekspresyjny i wielosłowny sposób pisania Konińskiego kryje treści łatwiejsze do rekonstrukcji. Wreszcie, Weil pochodziła z rodziny żydowskiej, nie otrzymała żadnego wychowania religijnego, a jej zwrot ku chrześcijaństwu miał cechy mistycznego olśnienia, choć jak zapewniała, bez żadnych zmysłowych wizji ${ }^{21}$. Sytuacja Karola Ludwika Konińskiego była nieco odmienna. Jego ojciec, Karol Koniński, był konsekwentnym ateistą, zdecydował się ochrzcić syna z czysto formalnych powodów, bez tego aktu Karol junior nie zostałby przyjęty do galicyjskich szkół publicznych ${ }^{22}$. Przyjęcie chrztu w wieku lat dziesięciu zrobiło ogromne wrażenie na Karolu Ludwiku, także szkolna nauka katolicyzmu pogłębiła jego zainteresowania religijne, jednocześnie pozostawał on pod wpływem ojca - ateisty, człowieka wielkiej wiedzy i szlachetnego charakteru ${ }^{23}$. Koniński zmagał się z problemem religii do końca życia, nigdy nie uzyskawszy niezachwianej pewności.

19 O trwałości poglądów Konińskiego świadczy jego rękopis z 1942 roku pt. Człowiek i naród, zawierający refleksje całkowicie zgodne z jego wcześniejszą publicystyką. Por. K.L. Koniński, Cztowiek i naród, [w:] tenże, Kartki z brulionów, s. 55-66.

20 Cz. Miłosz, Wstęp, [w:] S. Weil, Wybór pism, przeł. i oprac. Cz. Miłosz, Kraków 1991, s. 5-13.

21 S. Weil, List pożegnalny do ojca J.M. Perrin, Dominikanina, [w:] taż, Wybór pism, s. 35.

22 K. Wyka, Koniński Karol, [w:] Polski stownik biograficzny, t. 13, s. 532; B. Mamoń, Karol Ludwik Koniński, s. 9-10.

23 B. Mamoń, Karol Ludwik Koniński, s. 35-38. 
Kwestią jeszcze bardziej fundamentalną od problemu Boga i sensu postawy religijnej było u Konińskiego rozróżnienie na życie wartościowe i niewartościowe. Egzystencjalną prawdą było dlań stwierdzenie, że życie wartościowe, napełnione miłością, rozumem i pracą, jest najwyższym okazem życia ${ }^{24}$. Koniński deklarowal, że nieistnienie byłoby lepsze od istnienia marnego: Jeśli jest Bóg, o którym Jezus nauczat, to dla niego optaci się być nawet ohydnym i obrzydliwym. Jeśli On jest tylko fikcja naszych serc, to nie wolno wyrzekać się moralności dumnych: niech się czyści świat z nieudanych, jeślim i ja nieudany, niech przepadam, niech ginę! ${ }^{25}$ Autor Nox atra stawiał sobie jako jednostce zadanie zdobycia doskonałości zapewne nieosiągalnej dla człowieka (jak zobaczymy, podobnie niebotyczne cele wyznaczał Polakom jako wspólnocie narodowej). Tym, co nadaje życiu wartość, była dlań aktywność, której celem miało być doskonalenie moral$n \mathrm{e}^{26}$. Metafizyka Konińskiego była podporządkowana temu przekonaniu: skoro najwartościowsze życie cztowieka, to jest życie czynne, praca, mająca na celu obiektywne cele, skoro to są pewniki sumienia, więc i myśl metafizyczna, w szczególności teologiczna, powinna zawsze nawracać do tego życia przeżyć i życia czynów ${ }^{27}$.

Życie wartościowe jest więc życiem moralnym, najważniejszym aspektem człowieczeństwa jest sumienie, rozum jedynie jego sługą. W sumieniu zaś autor Ex labyrintho odnajdywał przede wszystkim pragnienie dobra, najwyższym zaś imieniem tego dobra był Bóg. Stąd też: Dobry cztowiek pragnie, ażeby byt Bóg. Bo wtedy sprawa Dobra ma znacznie lepsze szanse. Bógpowinien być - to jest postulat dobroci. Czy jest Bóg, czy dobroć nie jest catkiem odosobniona w świecie - to jest kwestia faktu ${ }^{28}$. Pragnienie dobra przekraczającego zwykłe ludzkie cele uprawdopodabnia zaś wedle Konińskiego jego ponadnaturalne pochodzenie. Jego etyczny argument za istnieniem Boga wydaje się uwikłany w błędne koło, wszelako nie było to dla Konińskiego problemem, skoro u jego podstaw leżało niezaprzeczalne przeżycie egzystencjalne ${ }^{29}$.

Zarys takiego rozumowania widoczny był w przedwojennej publicystyce autora Nox atra. W artykule $W$ sprawie Ch. O. Ś. („chrześcijańskiej odbudowy świata”) z 1938 roku pisał on o zmaganiu się wiary z niewiarą jako o trwałym elemencie kultury. Wyraźnie przy tym wywodził wiarę z doświadczenia egzystencjalnego jednostki, nie

24 K.L. Koniński, Ex labyrintho, s. 135.

25 Tenże, Nox atra, s. 10.

26 Warto zauważyć, że Koniński z uznaniem wypowiadał się o humanizmie ateistycznym, który dostrzegał u Brozowskiego, stwierdzając w jego postawie życiowej: wspaniatość i wzniostość heroizmu ateistycznego: wszystko zaczyna się tu, ode mnie, w tym punkcie czasu i przestrzeni, tu rodzi się wartość, tu żyję dla wartości, wszystko jedno czy wartość trwa w czasie dtugo czy krótko, czy wartość przetrwa śmierć czy nie przetrwa, dość, że zaistniata choć na moment, na tle czarnym rozbtysta wspaniale - jak ptomień - $i$ warto w tym ptomieniu spalić się, nie pytając zresztą o nic. K.L. Koniński, Uwagi 1940-1942, s. 87.

27 Tenże, Ex labyrintho, s. 41.

28 Tami̇e, s. 42.

29 Niezwykle podobne jest uzasadnienie idei Boga u Simone Weil: Jestem zupetnie pewna, że jest Bóg, $w$ tym sensie: jestem zupetnie pewna, że moja mitośćnie jest ztudzeniem. Jestem zupetnie pewna, że nie ma Boga, $w$ tym sensie: jestem zupetnie pewna, że nic rzeczywistego nie odpowiada temu, co moge pomyśleć, wymawiając to imię. Ale to, czego nie mogę pomyśleć, nie jest ztudzeniem. Por. S. Weil, Wybór pism, s. 59. 
zaś z objawienia dokonanego przez siły boskie: Jest Dobroćpośród strasznego świata - to wątpliwości nie ulega - wszak widzimy dobrych pomiędzy ztymi. Dobroć, czyli Mitość, wykwieca z siebie metafizyczna Nadzieje, Nadzieja gestnieje w Wiare, a Wiara doświadcza Boga $^{30}$.

Wydaje się, że opisana postawa Konińskiego wobec podstawowych kwestii egzystencjalnych zbliżona jest do tych myślicieli, którzy przemyślawszy konsekwencje tryumfującego, po odkryciach Darwina, naturalizmu, zapragnęli przezwyciężyć niektóre konsekwencje tegoż. Jednym z filozofów pragnących uniknąć nihilistycznych konsekwencji naturalizmu był Jean Marie Guyau, myśliciel popularny w początkach XX wieku, a bez wątpienia znany Konińskie ${ }^{31}$. Jego książka Zarys moralności bez powinności i sankcji została wydana w polskim przekładzie w 1910 roku Guyau, nie widząc rozumowego uzasadnienia czynów moralnych, powiadał: Można tego dokonać tylko za pomoca hipotezy; muszę więc ostatecznie stworzyć sobie metafizyczne powody moich czynów. [...] Jeżeli chce na przyktad spetnić czyn czystego, bezwzględnego mitosierdzia i rozumowo uzasadnić go, musze sobie wyobrazić wieczne mitosierdzie, obecne wistocie rzeczy we mnie, musze uprzedmiotowićuczucie, które mi każe dziatac ${ }^{32}$. Innym filozofem głoszącym ideę samodoskonalenia moralnego na przekór tendencjom naturalistycznym i utylitarystycznym był Otto Weininger ${ }^{33}$. U Konińskiego nie brak motywów weiningerowskich, wyraźnie przeciwstawiał on męską wstrzemięźliwość, intelekt, pracę i postawę etyczną kobiecej cielesności, zmysłowości i popędliwości ${ }^{34}$. Wymienieni myśliciele, zaliczani do „filozofów życia”, jak też Friedrich Nietzsche byli ważnym punktem odniesienia dla Konińskiego. Tym, co różniło go od nich, było zdecydowane otwarcie na myśl chrześcijańską ${ }^{35}$.

Koniński jako myśliciel religijny nie był właściwie myślicielem katolickim. Choć należał do Kościoła formalnie, zaś w publicystyce zaliczał się czasem do „obozu bogojczyźnianego", nie był w stanie bezkrytycznie przyjąć katolickiej ortodoksji. Szczególny sprzeciw budziła w nim wizja Boga, który jednym daje łaskę zbawienia, a innym nie. Wielokrotnie zastanawiał się nad tym, że jakkolwiek by ująć problem zła, to przyznanie Bogu atrybutu wszechmocy implikuje, że i zło pochodzi od Boga. W proteście przeciw

$30 \quad$ K.L. Koniński, W sprawie Ch. O.S. (O wspótczesnej sytuacji religijnej), [w:] tenże, Zagadnienia religijne..., s. 165.

31 Koniński wspomina Guyau między innymi w swoim szkicu o Nocach i dniach Marii Dąbrowskiej, w którym przedstawia go jako optymistycznego filozofa życia. Por. K.L. Koniński, Noce i dnie (O powieści Marii Dąbrowskiej), [w:] tenże, Szkice krytyczne..., s. 147.

32 J.M. Guyau, Zarys moralności bez powinności i sankcji, Warszawa 1960, s. 201.

33 Por. O. Weininger, Pteć i charakter, przeł. O. Ortwin, Warszawa 1994. O mizoginizmie Weiningera por. M. Uliński, Kobieta i mężczyzna. Dzieje refleksji filozoficzno-spotecznej, Kraków 2001, s. 212-221.

34 Charakterystyczny jest zapis w Ex labyrintho: Gnicie spoteczne zaczyna się lub objawia przede wszystkim w buncie kobiet - przeciwko wstydliwości narzuconej im przez twarde sugestie świata męskiego, pracujacego, walczacego, pragnacego mocnymi bulwarami obyczaju seksus zdyscyplinować, po to aby nie być przez kobietę zawsze i na każdym kroku niepokojonym i prowokowanym, by móc dla swych męskich celów energię i czas zaszanować. K.L. Koniński, Ex labyrintho, s. 280. Innym razem Koniński zauważa, że rozpowszechnianie „nudyzmu” zagraża „idealizmowi młodzieży”. Tenże, Uwagi 1940-1942, s. 120.

35 O religijnych inspiracjach Konińskiego szeroko pisze Łukasz Front, nie dochodząc jednak do jednoznacznych wniosków. Por. Ł. Front, Myśl religijna..., s. 133-215. 
takiej wizji Koniński posunął się do stwierdzenia: lepiej, aby nie byto Boga, niż żeby byt Bóg, który mając moc zbawić wszystko, wszystkim dawszy duszom taskępokonania w sobie grzechu, daje ja tylko niektórym ${ }^{36}$. Stąd też za z gruntu złą uważał doktrynę Augustyna z Hippony o lasce, która jest swobodną wolą Boga ${ }^{37}$. Od doktryny Augustyna Koniński wolał ideę apokatastasis Orygenesa, czyli ostateczny powrót wszystkich bytów do Boga.

Potępiwszy Augustyńską doktrynę łaski, autor Nox atra był jednak zafascynowany świętością. Dążenie do świętości pojmował z jednej strony jako przekroczenie trywialności ziemskiego życia, nadające mu wartość, z drugiej jako ślad ponadludzkiej obecności w świecie: Świętość jest bezsensowna, jeżeli Boga nie ma. I tak musi być. Świętość musi być straszna, nie może być tatwa i zrozumiata, jeżeli Bóg jest, i jeżeli jest z drugiej strony jako fakt dany Ziemia. Tylko tym swoim maksymalizmem nieposkromionym, dla uczuciowości naturalnej absurdalnym, świętość dowodzi, że nie jest z tego świata $a^{38}$. Ze względu na świętość twórców tradycji chrześcijañskiej można mieć też nadzieję, choć nie pewność, $\dot{z}$ e przekazuja oni istotnie objawiona prawdę ${ }^{39}$. W innym znów miejscu Koniński dowodzi, że istnienie idei Boga w ludzkim sumieniu świadczyć może o tym, że sam Bóg ją w nim ukształtowal ${ }^{40}$. Na różne sposoby autor Ex labyrintho badał prawdopodobieństwo tego, że Bóg jako postulat sumienia tożsamy jest z Bogiem doktryny chrześcijańskiej, rozumiał jednak, że prawdopodobieństwo nie jest pewnością.

Indywidualistyczna religijność Konińskiego, ujawniona najpełniej w jego pismach czasu wojny, nie należała do żadnej istniejącej wówczas tradycji teologicznej. Nie przystawała też do żadnego wyznania ${ }^{41}$, mało zresztą znajdziemy eklezjologii w Nox atra czy $E x$ labyrintho. Jednak inspiracją do tych wszystkich rozważań była tradycja katolicka i realnie istniejący Kościól, z którym Koniński zetknął się w wieku lat dziesięciu. Prowadziło to do dylematu, który wyraził już we wcześniejszej publicystyce: kto chce być religijnym indywidualistą, musi przeciwstawić się potędze Kościoła, przez co jednak przeciwstawia się wartościom, jakie niesie wspólnota kościelna. Ambiwalencję tę wyraził Koniński w szkicu O cztowieku polskim z 1936 roku, pisząc: Jeśli są między chrzczonymi w Kościele katolickim ludźmi tacy, którzy, w rozmaitych zreszta sensach, ale nieztomnie i niewątpliwie czują się chrześcijanami - jeśli ci ludzie zostać chca "wolnymi w duchu” - to co mają zrobić? Czy przetamać $w$ sobie ten rdzenny polski koncyliaryzm - i zdobyć się na decyzję tragiczną? Czy też raczej ulec temu polskiemu pragnieniu jednania przeciwieństw i temu naszemu praktycznemu realizmowi i melioryzmowi, który $w$ Kościele widzi potężna rzeczywistość, jaka podtrzymywać należy, potencjaty jej aktualizując, niż zwalczać i podkopywać? ${ }^{42}$

36 K.L. Koniński, Nox atra, s. 20.

37 Tamze, s. 21-22.

38 Tamże, s. 98.

39 Tenże, Ex labyrintho, s. 47.

40 Tamże, s. 105.

41 Enigmatycznie wyrażają to słowa z listu Konińskiego do Turowicza: Ja nie jestem tak zdecydowanym katolikiem jak Pan. Por. Karol Ludwik Koniński do Jerzego Turowicza, Odwaga i rzetelność, [w:] Przeciw antysemityzmowi 1936-2009, t. 1, red. A. Michnik, Kraków 2010, s. 442.

42 K.L. Koniński, O cztowieku polskim. Na jubileusz Ignacego Chrzanowskiego, [w:] tenże, Pisma politycz- 
Bez wątpienia takim chrześcijaninem w pewnym sensie, a zarazem „wolnym w duchu" czuł się sam Koniński, zaś przedstawiony dylemat był jego osobistym problemem. Jeśli bowiem wartościowe jest życie twórcze i przepełnione miłością, to przecież dokonuje się ono w kontekście kultury, w której istnieją już pewne wzorce i normy wypracowane przez dawniejsze pokolenia i podtrzymujące istniejące wspólnoty ludzkie. Polemizując z przyziemnym i mało ambitnym jego zdaniem libertynizmem Boya-Żeleńskiego, Koniński stwierdzał: Zmyst religijny znaczy, że się cztowiek wyrywa ponad samego siebie, ponad przyrodę. Tak w catej petni czuja i żyja tylko wybrani - święci. Ale na tych duchach oparta sie i rozbudowata cata ta kultura, która się zowie chrześcijańską. Pęd ponad ten świat jest ostatecznym zaczynem cywilizacji chrześcijańskiej j3.

Cywilizacja ta pozostawała kontekstem, w jakim odbywały się egzystencjalne poszukiwania życia wartościowego, których dokonywał autor Nox atra. Z kolei w ramach tej cywilizacji naród okazywał się wspólnotą kultury umożliwiającą udział w procesie cywilizacyjnym. W obrębie tych wspólnot dokonuje się postęp całej ludzkości. Istotny postęp winien być oceniany z punktu widzenia tego, co Koniński nazywa „zasadą ciągłości cywilizacyjnej", zgodnie z którą: każdą nowa, przystępująca do dziatania tendencje życiowa ocenia się z tego punktu widzenia, jak ona dziata na cata resztę tendencji, czy ona się z nimi harmonizuje, czy też zespót ich rozprzega i pozostawia chaos ${ }^{44}$. Taki postęp jest możliwy tylko w ramach kultury narodowej, próżno bowiem czekać na moralny konsens całej ludzkości ${ }^{45}$.

Koniński najwyraźniej nie widział możliwości wartościowego życia dla siebie poza kontekstem cywilizacji chrześcijańskiej i poza wspólnotą narodową, rozumianą jako kulturalna i polityczna jednocześnie. W myśli Konińskiego zarówno potrzeba religii i wspólnoty religijnej, jak i potrzeba wspólnoty realnie bliższej, czyli wspólnoty narodowej, były wywiedzione z fundamentalnych doświadczeń egzystencjalnych. Uznawał on wyraźne związki między nimi, religia uczy bowiem życia wartościowego, zaś wspólnota narodowa daje możliwość realizacji tej potrzeby. Jednak związki konkretnej wspólnoty narodowej z konkretną religijnością Koniński postrzegał jako efekt historycznego przypadku ${ }^{46}$. Stąd też, uznając związek polskości z katolicyzmem, postrzegał pielęgnowanie tegoż związku raczej jako wyraz „zaufania do rzeczywistości” niźli wynik zrządzeń boskiej Opatrzności ${ }^{47}$.

ne, s. 419-420.

43 Tenże, Boy, [w:] tenże, Pisma polityczne, s. 222.

44 Tenże, Obyczaj i myśl, [w:] tenże, Pisma polityczne, s. 202-203.

45 Tamże, s. 203.

46 Tenże, Nacjonalizm, religia, wolność. Obyczaj i myśl, [w:] tenże, Zagadnienia religijne..., s. 129-134.

47 W artykule o tym tytule opublikowanym w 1929 roku w „Myśli Narodowej” Koniński zapytywał o możliwość mobilizacji sił przeciw ewentualnej rewolucji bolszewickiej i znajdował je w chrześcijaństwie i tradycji katolickiej. W jego rozumieniu chrześcijaństwo było główną siłą zdolną przeciwstawić materialistycznemu bolszewizmowi zasoby cywilizacji „spirytualistycznej”. Zob. tenże, Zaufanie do rzeczywistości, [w:] tenże, Zagadnienia religijne..., s. 54-75. 


\section{NARÓD JAKO DZIEŁO TWÓRCZYCH ELIT}

Analiza pism Konińskiego prowadzi do wniosku, że fundamentalne znaczenie w jego myśleniu ma egzystencjalna analiza ludzkiej jaźni. Odkrywa ona potrzebę dążenia do dobra jako najważniejszy składnik swej egzystencji. Z tej potrzeby Koniński wywodzi pojęcie Boga jako postulatu moralnego. Praktycznym aspektem tych dążeń jaźni jest postulat życia wartościowego, życie bezwartościowe byłoby bowiem nieznośne i nie do przyjęcia. To z kolei prowadzi do potrzeby twórczej pracy, która dokonuje się zawsze w ramach pewnej kultury i wspólnoty ludzkiej: cztowiek, w potężnym parciu do wydobycia się z otoczy swej epistemologicznej samotni, buduje sobie świat, który go wiąze, ogranicza, coraz mniej liczne wyznacza mu alternatywy wyboru ${ }^{48}$. Efektem tej pracy jest cywilizacja i wspólnota narodowa. Koniński wyraźnie utrzymywał, że zachowanie wspólnoty narodowej jest warunkiem życia moralnego. Albowiem rozpad wspólnoty narodowej prowadzi do przewagi dążeń indywidualnych i grupowych, które niszczą wspólnotę ludzką: Kto rozbija ideat narodowy danego spoteczeństwa, ten sprawia, iż wszelkie grupy zawodowe, a z kolei i osobniki, przestając się poczuwać do wspólności, dezorganizują nieuniknienie życie spoteczne ${ }^{49}$. W innym miejscu autor nasz stwierdzał: Ostabiać nacjonalizm, czyli po prostu namiętne przywiazanie do bytu narodowego, to znaczy sprzeciwiaćsię jedynemu możliwemu a wspólnemu wyrazowi czynników cywilizacyjno-twórczych danego faktycznego zespotu. To zaś prostą droga prowadzi ostatecznie do anarchii i materialnego bankructwa danego spoteczeństwa ${ }^{50}$. Jak wyjaśnia Koniński, w miarę rozwoju cywilizacyjnego poczucie obowiązku jednostek coraz mniej wiąże się z ich materialnym, jasno zrozumiałym interesem. Stąd warunkiem trwania społeczeństwa jest związek z istniejącą realnie wspólnotą polityczną istniejący dzięki poczuciu odpowiedzialności za losy tejże wspólnoty ${ }^{51}$.

Inspirację swej kulturalistycznej teorii narodu czerpał Koniński od autorów epoki modernizmu ${ }^{52}$. Stanisławowi Brzozowskiemu zawdzięczał poczucie łączności z procesem dziejowym, w ramach którego obowiązkiem moralnym jednostki jest przetworzenie dokonań wcześniejszych pokoleń. W tekście ogłoszonym w „Myśli Narodowej” w 1930 roku pisał Koniński: Brzozowski napawa poczuciem „dziejowości”, tj. wzniostym a niewolacym poczuciem ścistej solidarności z procesem cywilizacyjnym. Takiej samej zaś politycznej w najszerszym i najprostszym tego stowa znaczeniu postawy duch a domaga sie i treść jej wypracowuje nacjonalizm ${ }^{53}$.

48 Tenże, Struktura i symbol narodu, [w:] tenże, Pisma polityczne, s. 54.

49 Tamże, s. 67.

50 Tenże, Cztowiek zupetny, twórca i naród (zpowodu książki Tagorego), [w:] tenże, Pisma polityczne, s. 43.

51 Tamże, s. 34-35.

52 Obszernie, choć mało konkluzywnie, pisze o pojęciu narodu u Konińskiego Łukasz Front. Charakterystyczne jest pomijanie przez tego autora antyżydowskich wypowiedzi Konińskiego. Por. Ł. Front, Myśl religijna..., s. 315-338.

53 K.L. Koniński, Na tropach frazesu, [w:] tenże, Pisma polityczne, s. 226. 
Innym autorem, na którego powoływał się Koniński, był Zygmunt Wasilewski, redaktor „Gazety Warszawskiej”, później zaś „Myśli Narodowej”, w okresie międzywojennym odgrywający rolę autorytetu wśród literatów związanych z obozem narodowym ${ }^{54}$. U Wasilewskiego znajdował Koniński mocne argumenty za tezą, że uczestnictwo w cywilizacji za pośrednictwem wspólnoty narodowej jest warunkiem moralnego rozwoju jednostki ${ }^{55}$.

Wedle Konińskiego naród (a można sądzić, że także religia) okazują się efektem twórczej pracy jednostek przewyższających inne energią i wolą w dążeniu do wartości: Naród jest spoteczno-obiektywna emanacją tych cywilizacyjnie twórczych dusz, których moralnym prawem jest zagarniać rzeczywistość sposobem ciagtym, a nie skaczacym ${ }^{56}$. Inaczej mówiąc, powstanie i rozwój wspólnoty narodowej jest efektem pracy elit - szeroko rozumianych twórców kultury.

Taka kulturalna teoria narodu nie została przez Konińskiego zbyt ściśle powiązana z konkretnymi faktami historycznymi. W cytowanym szkicu Struktura i symbol narodu Koniński kreśli jedynie teorię formowania się narodu na terytorium mieszanym etnicznie. Oto grupa etniczna mająca tylko kulturę ludową zyskuje z czasem warstwę oświeconą, która pragnie udostępnić ludowi dobra kultury wyższej w jego własnym języku. Ta praca kulturalna prowadzi do pojawienia się ambicji kulturotwórczych w nieaktywnym dotychczas środowisku. Raz uruchomiony proces narodotwórczy zyskuje swoją dynamikę, liderzy kształtującej się wspólnoty starają się wzbudzić w niej dumę narodową poprzez kontakt z osiągnięciami cywilizacji, do której dana grupa etniczna należy. Proces taki jest poniekąd kwestią historycznego zbiegu okoliczności. W egzystencjalnej antropologii narodu Konińskiego nie ma miejsca na prowidencjonalizm: Naród nie ma żadnego celu, jak go nie ma w ogóle żadne życie; naród ma tylko przyczynę, non causam finalem sed causam efficientem ${ }^{57}$. Inaczej mówiąc, wyodrębnienie narodu nie jest żadną koniecznością dziejową, jednak naród raz wyodrębniony staje się dla jednostek moralną koniecznością „zawężającą możliwości wyboru”, bo tylko w ramach narodu możliwa jest twórczość dodająca do kultury istotne wartości. Specyficzną wartość polskiej kultury Koniński upatrywał w idei wolności politycznej, jaką niosła tradycja dawnej Polski.

W przekonaniu Konińskiego okres braku niepodległości był sprawdzianem moralnej wartości zawartej w polskiej tradycji narodowej. Jego zdaniem: co nas podczas niewoli wiąato $w$ naród, to przede wszystkim ten ideat wolnego cztowieka, jaki, bądź co bąź, mimo wszystkie zboczenia i btedy, polska demokracja szlachecka zdotata dziejami swymi przed wyobraźnia swoja ustawićs8. Upatrywanie w Polsce szlacheckiej realizacji

54 Por. M. Urbanowski, Nacjonalistyczna krytyka literacka. Próba rekonstrukcji i opisu nurtu w II Rzeczypospolitej, Kraków 1996, s. 25-35; E. Prokop-Janiec, Literatura i nacjonalizm. Twórczość krytyczna Zygmunta Wasilewskiego, Kraków 2004, Modernizm w Polsce, 1.

55 K.L. Koniński, Dwie postaci konkretywizmu (patriotyzm liberalny inacjonalistyczny), [w:] tenże, Pisma polityczne, s. 83 i n.

56 Tenże, Struktura i symbol..., s. 61.

57 Tami̇e, s. 59.

58 Tenże, Dialektyka nacjonalizmu (uwagi o książe Rene Johanneta), [w:] tenże, Pisma polityczne, s. 270-271 . 
ideału wolności politycznej, a także indywidualnej było stanowiskiem obecnym w publicystyce epoki. Koniński zapewne znał pisane w tym duchu książki: Ducha dziejów Polski Antoniego Chołoniewskiego i Ku czemu Polska szta Artura Górskiego. Szczególnie ta pierwsza wzbudziła szeroką dyskusję, która przypadła na okres, kiedy Koniński rozpoczynał swoją działalność publicystyczną̧

Tendencja do rehabilitacji, a nawet apologii Polski szlacheckiej wzmagała się w obozie narodowym po odzyskaniu niepodległości, podczas gdy jeszcze w Myślach nowoczesnego Polaka Dmowski zdecydowanie negatywnie oceniał stulecia poprzedzające rozbiory, stwierdzając: rozwój spoteczności naszej, wyszedtszy z wtaściwej kolei dziejowej, oddalat się coraz bardziej od tej linii, która jej mogta zapewnić wielka przysztość [...] naród nasz usunąt się w krótkim czasie na tyty pochodu cywilizacyjnego ${ }^{60}$.

Koniński, który przyznawał się do fascynacji wczesnymi pismami Dmowskiego, daleki był od pełnej rehabilitacji szlacheckiej Rzeczpospolitej, ale podzielał pogląd wyrażany przez Chołoniewskiego ${ }^{61}$, że wolnościowe tradycje dawnej Polski stanowią przeciwwagę dla tendencji autokratycznych i militarystycznych w Europie ${ }^{62}$. Stąd wyprowadzał przekonanie o tym, że Polska jest potrzebna Europie i ludzkości.

Pogląd taki znaleźć można zarówno w międzywojennej publicystyce Konińskiego, jak i w jego późnych pismach. O trwałości tych poglądów świadczy notatka w Ex labyrintho, w której argument wywiedziony z kulturalnej teorii narodu sąsiaduje $\mathrm{z}$ argumentem geopolitycznym: $w$ trwanie Polski inwestowano więcej heroizmu niż $w$ trwanie innych narodów, które katastrofy historycznej nie przeszty lub które, przeszedtszy ja, nie zapracowaty tak jak my na swoją odnowę. Ponadto jesteśmy potrzebni w tym miejscu, trzeba, abyśmy byli wielcy i bezpieczni, jeśli Europa wolności ludzkiej ma być bezpieczna ${ }^{63}$. Podobną refleksję znaleźć można w Uwagach ${ }^{64}$. Rola Polski jako ośrodka wolności przeciwstawiającego się autokratycznym reżimom miała być wynikiem dotychczasowego procesu historycznego. $\mathrm{Z}$ niego nasz autor wyprowadzał heroiczne zadania, jak się okazało, wyraźnie ponad siły Polaków.

Koniński zdawał sobie sprawę z niepewności i nieoczywistości bytu państwowego Polski odrodzonej. Podobnie jak wielu myślicieli politycznych II Rzeczypospolitej podzielał pogląd, że warunkiem utrzymania niepodległości jest zdobycie przez Polskę mocarstwowego charakteru. Przywódcy endeccy lat 20. rozumieli przez to zdolność do obrony zarówno przed Niemcami, jak Rosją sowiecką. „Mocarstwowość” Polski była w tym ujęciu zasadniczo tożsama ze zdolnością do niepodległego bytu, stąd też wynika

59 A. Wierzbicki, Wokót Ducha dziejów Polski. Spory o ocenę dziejów narodowych w historiografii polskiej 1917-1919, „Kwartalnik Historyczny” 1971, R. 78, nr 4, s. 840-856; J. Maternicki, Idee i postawy. Historia i historycy polscy 1914-1918. Studium historiograficzne, Warszawa 1975, s. 342-352.

$60 \quad$ R. Dmowski, Myśli..., s. 14.

61 A. Chołoniewski, Duch dziejów Polski, Kraków 1918, zwł. s. 10-11, 48, 108-109, 118.

62 Można wskazać licznych poprzedników tej idei w osobach Joachima Lelewela, Adama Mickiewicza, ideologów Towarzystwa Demokratycznego Polskiego czy Stefana Buszczyńskiego.

63 K.L. Koniński, Ex labyrintho, s. 136.

64 Tenże, Uwagi 1940-1942, s. 146-147. 
przekonanie Konińskiego, że: cata nasza myśl polityczna organizować się musi wedtug tego pytania: Jak uczynić Polskę mocarstwem?65

Prowadziło to do niezwykle trudnej kwestii stosunku do mniejszości narodowych. Myśl obozu narodowego odrzucała sprowadzenie Polski do granic etnicznych, nie tylko z powodu trudności wytyczenia takich, ale dlatego, że Polska ograniczona do ziem rdzennie polskich byłaby zbyt słaba, aby obronić swą niezależność. Jednak utrzymanie w granicach kraju znacznej liczby ludności niepolskiej poważnie utrudniało rządzenie państwem. Endeckim rozwiązaniem tego problemu był postulat polonizacji mniejszości słowiańskich oraz izolacja i nakłanianie do emigracji ludności żydowskiej ${ }^{66}$. Koniński podzielał ten drugi postulat, ale zdawał sobie sprawę z nierealności programu polonizacyjnego ludności „rusińskiej”.

\section{TRWANIE I WIELKOŚĆ NARODU JAKO KONIECZNOŚĆ EGZYSTENCJALNA}

Koniński podzielał poglądy przywódców obozu narodowego na sytuację Polski odrodzonej. Rozumiał, że jej niepodległość nie jest pewna, a sytuacja międzynarodowa może się zmienić. Za główne zagrożenie uważał Niemcy, natomiast Związek Sowiecki postrzegał jako groźny, ale przejściowo niezbyt skłonny do poważniejszej akcji antypolskiej. W takim położeniu tylko Polska „wielka” albo „mocarstwowa” może utrwalić swój byt. Dla Konińskiego wielkość Polski była egzystencjalną koniecznością: Obowiazkiem naszym strasznym i wielkim jest stworzyć sitę Polski. Do sity potrzeba wielkości. Jeśli nie stworzymy wielkości polskiej - to nasi synowie i synowie naszych synów i tak po wiek wieków - będa nie ludźmi wolnymi, ale mottochem podtym, haniebnym i tchórzliwym, zgrają stugusów. To są rzeczy przerażająco oczywiste ${ }^{67}$. Alternatywą dla wielkości była marność życia zbiorowego, która autora Nox atra przerażała tak samo jak marność życia jednostkowego. Koniński pragnął budować tę wielkość na gruncie kultury i czystej polityki.

Zadziwiające jest u niego ignorowanie sfery materialnej, trudno bowiem mówić o sile państwa, nie wspominając o jej gospodarczych podstawach, te zaś zostały całkowicie pominięte w publicystyce Konińskiego. Kontrastuje to z postawą wielu ideologów endecji należących do głównego nurtu. Potrzebę rozwoju gospodarczego jako bazy postulowanej mocarstwowości rozumieli ekonomiści z obozu narodowego Stanisław Grabski i Roman Rybarski ${ }^{68}$. Można sądzić, że twórcza praca elit obejmowała w rozumieniu Konińskiego także wszelki wysiłek w sferze gospodarczej, jednak nie miał on wiele do powiedzenia w tej sprawie. Postawa taka miała w jakimś stopniu charakter

65 Tenże, Dialektyka nacjonalizmu..., s. 273.

66 Por. E. Maj, Związek Ludowo-Narodowy 1919-1928. Studium z dziejów myśli politycznej, Lublin 2000, s. 242-257.

67 K.L. Koniński, Cesarstwo polskie, [w:] tenże, Pisma polityczne, s. 427-428.

68 Więcej o tym por. D. Grzybek, Polityczne konsekwencje idei ekonomicznych w myśli polskiej 1869-1939, Kraków 2012, s. 216-220, 244-249, Societas, 32. 
ucieczkowy. Słabość gospodarcza Polski międzywojennej należała do sfery faktów, których trudno było nie zauważać. Produkcja przemysłowa w Polsce w 1938 roku zaledwie dorównywała produkcji na tym samym terytorium w roku 1913, w wielu branżach była znacznie niższa. Zważywszy na to, że liczba ludności istotnie wzrosła, nie ulega wątpliwości, że wielkość produkcji na mieszkańca znacznie spadła ${ }^{69}$. Wśród krajów międzywojennej Europy, dla których są przybliżone choćby dane liczbowe, jest to jedyny taki przypadek ${ }^{70}$. Nie mogąc liczyć na potęgę militarną ani bogactwo materialne, Koniński stawiał na wielkość idei jako podstawę politycznej wielkości Polski. Było to powtórzenie romantycznego przekonania o odrodzeniu Polski jako funkcji wysiłku duchowego.

Koniński podzielał endecką koncepcję narodu rządzącego, zgodnie z którą państwo polskie jest własnością narodu polskiego i tylko etniczni Polacy mogą nim rządzić. Idea państwa równouprawnionych narodowości nazywana była przez endeckich przywódców „państwem narodowościowym” i zdecydowanie odrzucana. Stanowisko Konińskiego w tej kwestii dobrze wyraża jego opinia, że: Jak dotąd, nam tylko Polakom na Polsce zależy i dopóki z catą oczywistością to się nie zmieni, nie możemy, bez narażania się na rozdarcie, sterem państwa polskiego dzielić się z kimkolwiek ${ }^{71}$. Jednocześnie rozumiał on, że program polonizacji słowiańskich mniejszości narodowych jest mało realny. Co więcej, zetknięcie się z silnym, wspartym na bogatej kulturze nacjonalizmem polskim wzmacnia własne uczucia narodowe wśród Ukraińców i innych „Rusinów”. Stąd akcja polonizacyjna daje skutki przeciwne do zamierzonych: $Z$ chwila, gdy państwo narodowe, dązac do tego, by stać sie jednonarodowym, usituje swych obywateli obconarodowych zasymilować, dajac im wtasna kulture - to kultura ta, przesiaknięta idea narodowa, wytwarza temu państwu przeciwników $w^{72}$. W tej sytuacji zmiana na lepsze polegać mogła na przekonaniu mniejszości narodowych, że istnienie oraz „wielkość” Polski jest także w ich interesie. Jakkolwiek pogląd ten został delikatnie wyrażony, był on polemiczny wobec stanowiska przywódców obozu narodowego, a bliższy koncepcji „asymilacji państwowej" głoszonej przez zwolenników obozu rządzącego.

W sferze polityki międzynarodowej Koniński posiadał jasne rozpoznanie wrogów i przyjaciół. Głównym zagrożeniem dla Polski są Niemcy, drugorzędnym, lecz także poważnym Związek Sowiecki, zaś głównym sojusznikiem Francja. Strategicznym celem polityki polskiej powinno być zbudowanie ośrodka siły politycznej i militarnej, który przeciwstawiałby się zarówno Niemcom, jak i imperium sowieckiemu. Na tym miało polegać historyczne zadanie Polski, znamionujące jej wielkość: Polska potrzebna jest nie tylko Polakom. A skoro tak, to Polska ma wobec tych narodów jeden obowiazek i jedno prawo: dla wspólnego bezpieczeństwa skupić je dokota siebie i przewodniczyć im. Na tym polega wielkość Polski i Polski sita ${ }^{73}$.

69 J. Tomaszewski, Z. Landau, Polska w Europie i świecie 1918-1939, Warszawa 2005, s. 137-143; A. Jezierski, C. Leszczyńska, Historia gospodarcza Polski, Warszawa 1997, s. 280.

70 Por. C. Clark, The Conditions of Economic Progress, London 1957.

71 K.L. Koniński, Dialektyka nacjonalizmu..., s. 276.

72 Tamże, s. 265.

73 Tenże, Cesarstwo polskie, s. 428. 
Koniński nie wątpił, że Polska jest naturalnym przywódcą narodów środkowoeuropejskich. Jednak aby przekonać do projektu Austriaków i Węgrów, proponował projektowanemu związkowi nadać formę Cesarstwa Polskiego z monarchą pochodzącym z dynastii habsbursko-lotaryńskiej. Ów habsburski cesarz miał jednak rezydować nie w Wiedniu, a w Krakowie. Koniński zapewniał, że za jego propozycją nie kryją się żadne sentymenty monarchistyczne ani nawet jakaś filozofia polityczna, z której miałby monarchizm wynikać, a jedynie pragmatyka polityczna. Idzie o to, aby wszystkie ludy pomiędzy Niemcami a Związkiem Sowiecki skupić wokół Polski, co wymaga imperialnej formy, to zaś najlepiej osiągnąć, wykorzystując tradycję starej europejskiej dynastii. Imperium pod przywództwem Polski opierałoby się o trzy morza - Bałtyk, Adriatyk i Morze Czarne, miałoby siłę militarną równą innym mocarstwom, zaś wraz z Francją zdolne byłoby stabilizować sytuację polityczną Europy.

W samym tym pomyśle liczyła się nie tyle imperialna forma, ile przekonanie, że Polska ma dość siły i atrakcyjności, aby do takiego związku doprowadzić. Racjonalnym jądrem tej koncepcji było przekonanie, że Polska w kształcie wyłonionym po traktacie wersalskim i pokoju ryskim jest zbyt słaba, aby samodzielnie obronić się przed potężnymi sąsiadami ze wschodu i zachodu. Zupełnym złudzeniem było natomiast przypuszczenie, że związek państwowy z Polską może być atrakcyjny dla jej mniejszych sąsiadów z południa i północy. Fantazje Konińskiego wydają się wynikać z poczucia tragizmu: oto historyczne okoliczności sprawiają, że Polska musi się zdobyć na wielkość, aby przetrwać, a jednocześnie trudno się tej wielkości dopatrzyć w realnej Polsce. W swej publicystyce Koniński portretował Polskę rządzoną przez spadkobierców Piłsudskiego w wyraźnie ciemnych barwach. „Wielkość” była postulatem wynikającym z niezwykle trudnej sytuacji, egzystencjalną koniecznością, którą do aktualności sprowadzić mógł tylko akt woli dokonany w oparciu o wielką ideę. Owa, bardziej potencjalna niż realna, wielkość Polski miała także swój rewers, jakim była rzekoma niższość moralna jej żydowskich mieszkańców.

Kulturalistyczna teoria narodu chroniła Konińskiego przed wpływami rasizmu, które zawsze odrzucał. Jednak uznanie Żydów za „duchowo obcych” psychice polskiej dawało się łatwo uzasadnić na jej gruncie. W jego publicystyce Żydzi przedstawiani są jako ciało obce, duchowo nieprzystające do kultury polskiej, a społeczność żydowską uznaje się za nielojalną wobec państwa polskiego. Koniński opowiadał się także za społeczną izolacją Żydów i nakłanianiem ich do opuszczenia Polski. To ostatnie uważał za najlepsze rozwiązanie „kwestii żydowskiej”. Przekonanie, że Żydzi są dla Polski zagrożeniem, które należy usunąć, wzbudzał u Konińskiego już naoczny ogląd dzielnicy żydowskiej: Kiedy przechodzitem przez to okropne ghetto tódzkie, kiedy widziatem te rudery, cuchnace, wilgotne, wpadte $w$ ziemie - tom zrozumiat, że tam, wśród mtodzieży tam wyrostej nic innego gnieździć się nie może (o ile mtodzież ta wyzbędzie się swojej ortodoksji), tylko anarchizm i bolszewizm, zrozumiatem, że tam wtaśnie gromadzi się kadra, która wraz ze wszystkimi przestępcami, z catym lumpenproletariatem, czyha tylko na moment, w którym by rzucić się mogta na nasze miasto, zakatrupić nas ${ }^{74}$. Przy takim

74 Tenże, Taniec dialektyczny, czyli o humanizmie z zastrzeżeniami, [w:] tenże, Pisma polityczne, s. 330. 
oglądzie sprawy usunięcie Żydów z Polski mogło się wydawać jedynym rozsądnym wyjściem $\mathrm{z}$ beznadziejnej sytuacji.

Kulturalistyczna teoria narodu wspomagała powyższe wnioski, do których autor doszedł, używając metody fenomenologicznej. Skądinąd Koniński nie proponował tego samego wobec innych mniejszości narodowych i nie wyjaśniał tej różnicy, mniemając zapewne, że „obcość Żydów” jest dla czytelnika pojęciem dostatecznie zrozumiałym.

Wyeliminowanie Żydów i zastąpienie ich polskim, „chrześcijańskim” mieszczaństwem miało być także częścią przemian budujących wielkość Polski: To jest pewnik, ze naród, który by nie potrafit zdobyć swoich miast dla swego potomstwa i dla swego bezpieczeństwa i dla pomnożenia uczestników swej cywilizacji - taki naród bytby rasa niedotegów, bytby poniżej surowego patosu dziejów. Tym, co Żydom pozostaje, jest organizować swoja emigrację ${ }^{75}$. Tak jak przekonanie do Polski mniejszości nieżydowskich i skupienie wokół niej państw środkowej Europy, tak usunięcie z niej Żydów okazuje się w myśli Konińskiego koniecznością egzystencjalną.

Jego humanitaryzm przejawiał się w tym, że pragnął on żydowskich polemistów przekonać przy pomocy łagodnej perswazji, co miało służyć uniknięciu niepotrzebnej przemocy: Likwidacja żydostwa rozpoczyna się niechybnie i Żydzi maja do wyboru tylko: albo zachowywać się tak, by prowokować i usprawiedliwiać reakcje gwattowne, albo też konieczność tę zrozumieć jako nieuniknioną i uprawnionq ${ }^{76}$. Tak więc nasz autor jawnie przyznawał, że jego humanitaryzm nie obejmuje Żydów, kiedy zaś odwołują się oni do uniwersalnych norm, okazuje się to „prowokacją”. Dowodził przy tym, że Polska jako kraj posiadający wielkie historyczne dziedzictwo, zapewniający swym istnieniem ratunek idei wolności politycznej przed despotyzmem, ma w imię swej historycznej misji prawo do wygnania ze swego terytorium żydowskich obywateli.

Stanowisko Konińskiego wobec „kwestii żydowskiej” wydaje się spójne ze stanowiskiem narodowej demokracji, które wyłożył swego czasu Dmowski w broszurze Separatyzm Żydów i jego źródta, wydanej w roku 1909 (rzecz ukazała się wcześniej jako cykl artykułów w „Gazecie Warszawskiej”). Wedle Dmowskiego Żydzi stanowią społeczność zdecydowanie różną od Polaków, która z racji swej historii i kultury nie posiada właściwych Polakom „instynktów narodowych”77. Konflikt interesów i postaw zachodzący pomiędzy Polakami a Żydami to, zdaniem Dmowskiego, nieunikniony proces $d z i e j o w y^{78}$. Stąd rozwiązaniem „kwestii żydowskiej” nie może być asymilacja ani współpraca, zaś polski interes narodowy nakazuje zwalczać wpływy żydowskie ${ }^{79}$. Ów tekst wyznaczył oficjalne stanowisko endecji wobec Żydów, zaś w późniejszym okresie uległo ono jedynie radykalizacji ${ }^{80}$. Także Koniński podzielał opinię o zasadniczej obcości

\section{Tamże, s. 332.}

76 Tamże, s. 333.

77 R. Dmowski, Separatyzm Żydów i jego źródta, Warszawa 1909, s. 19, Kwestia Żydowska, 1.

78 Tamíe, s. 28.

79 Tamíe, s. 29.

80 W. Mich, Obcy w polskim domu. Nacjonalistyczne koncepcje rozwiazania problemu mniejszości narodowych 1918-1939, Lublin 1994, s. 53-89; O. Bergmann, Narodowa Demokracja wobec problematyki 
Żydów względem wszystkich społeczeństw europejskich. Jego zdaniem Żydzi byli: $n a-$ rodem bez ziemi pośród osiadtych, niechrześcijaniskim [...] pośród chrześcijaniskich, jednostronnie handlowym i spekulanckim pośród produkcyjnych ${ }^{81}$.

Antyżydowska postawa Konińskiego nigdy jednak nie była tak fundamentalna jak przywódców obozu narodowego. Radykalizacja postaw antyżydowskich w latach 30. wywołała sprzeciw Konińskiego, przyczyniła się do jego zerwania z obozem narodowym. Sprzeczność brutalnych wystąpień antyżydowskich z uniwersalistyczną etyką chrześcijańską budziła u niego niesmak i oburzenie, czemu dawał wyraz zarówno w publicystyce drukowanej ${ }^{82}$, jak i w prywatnych wypowiedziach ${ }^{83}$. Niemniej jednak spór z endecją dotyczył raczej metod niż celów, jego zdaniem stosowanie przemocy wobec Żydów kompromitowało antysemityzm, którego celem naczelnym jest zawiązanie wspólnoty narodowej zjednoczonej zbiorową wolą na gruncie wspólnej kultury: wybryki antysemickie osiagaja skutek przeciwny zamierzonemu, nasze spoteczeństwo bywa dość martwe, ale bądź co bądź nie ma sktonności brutalnych i na antysemityzm wulgarny reaguje raczej wspótczuciem dla jego ofiar, zniechęca się do obozu antysemickiego ${ }^{84}$. Tymczasem zorganizowany obóz „antysemicki” jest niezbędny ${ }^{85}$.

Koniński określał także swoje stanowisko jako „antysemityzm racjonalny”, którego istotą miałby być „moralny i gospodarczy system obronny”, albowiem rugowanie wpływów żydowskich miało być „uzdrawianiem” chorego społeczeństwa ${ }^{86}$. Można sądzić, że dla Konińskiego usunięcie Żydów z Polski było istotnym celem, w którego słuszność wierzył. Tymczasem przywódcy endecji i narodowi radykałowie raczej nie traktowali tych haseł zbyt poważnie, ich celem było podtrzymywanie wzajemnej wrogości, pragnęli bowiem wykorzystać antyżydowskie nastroje do mobilizacji politycznej swych zwolenników ${ }^{87}$.

Wydaje się, że antyżydowskie wystąpienia Konińskiego były w znacznym stopniu funkcją strachu przed rewolucją bolszewicką. W artykule Zaufanie do rzeczywistości z 1929 roku pisał on: Czy, w razie wypuszczenia mas na ulice przeciwko Państwu Polskiemu, przeciwko Biatemu Ortowi i przeciwko Krzyżowi - czy znajda się wtedy

żydowskiej w latach 1918-1929, Poznań 1998; M. Sobczak, Narodowa Demokracja wobec kwestii żydowskiej na ziemiach polskich przed I wojna światowa, Wrocław 2007; tenże, Stosunek Narodowej Demokracji do kwestii zydowskiej w Polsce w latach 1918-1939, Wrocław 1998, Prace Naukowe Akademii Ekonomicznej im. Oskara Langego we Wroctawiu, 796. Monografie i Opracowania, 124.

K.L. Koniński, Kilka truizmów w sprawie żydowskiej, „Gazeta Literacka” 1933, nr 10, s. 192.

Ciekawym tego świadectwem jest prywatny list Konińskiego do Turowicza, por. Karol Ludwik Koniński do Jerzego Turowicza..., s. 440-443.

84 K.L. Koniński, Logika swastyki, „Przegląd Powszechny” 1933, t. 197, s. 311.

85 Tamże, s. 311-312.

86 Tenże, Kilka truizmów..., s. 192-193.

87 Niektóre prywatne wypowiedzi przywódców endeckich potwierdzają to wprost. W rozmowie z Juliuszem Zdanowskim w lipcu 1925 roku Roman Dmowski otwarcie przyznawał, że nie chce ugody z Żydami, gdyż zmniejszyłoby to w Polakach „odruch przeciwżydowski”, tymczasem życzyłby sobie, aby Żydzi pozostali zantagonizowani z Polakami. Por. M. Sobczak, Stosunek Narodowej Demokracji..., s. 220. 
kontr-masy, dostateczne ilości ludzi, którzy będa mieli ochotę za Krzyż i Orta Biatego oddawać gtowy ${ }^{88} \mathrm{~W}$ tym starciu „materialistyczny” bolszewizm miał się zmierzyć z siłami „spirytualistycznej” cywilizacji chrześcijańskiej. Obawa przed potencjalną rewolucją typu bolszewickiego sprawiała, że wśród łódzkiego proletariatu żydowskiego nasz pisarz dostrzegał oczyma wyobraźni przyszłe kadry rewolucyjne. Koniński rozumiał, że nędza mas w Polsce jest poważnym problemem społecznym, mającym także wielki potencjał polityczny. W swej publicystyce wzywał do rozwiązania tego problemu w duchu solidarności narodowe ${ }^{89}$. Sądził najpewniej, że materialna nędza ludności żydowskiej w połączeniu z jej „obcością duchową” w konieczny sposób czyni Żydów przeciwnikami państwa polskiego. W ten sposób przekonanie Konińskiego o potrzebie mobilizacji przeciw bolszewizmowi przyczyniło się do tego, że jego stanowisko wobec „kwestii żydowskiej” wyrażone w drukowanej publicystyce mało różniło się od radykalnego szowinizmu, który zdominował dyskurs obozu narodowego w latach 30. Sukcesy hitleryzmu sprawiły, że Koniński począł się spodziewać rychłej konfrontacji z niemieckim szowinizmem, co niestety nie doprowadziło go do wycofania się ze stanowiska antyżydowskiego. „Racjonalny antysemityzm” Konińskiego nie odszedł zbyt daleko od zwykłego przesądu antyżydowskiego, którym posługiwali się przywódcy endecji.

\section{PODSUMOWANIE}

Idea narodowa Karola Ludwika Konińskiego wywodzi się z klimatu intelektualnego końca XIX wieku, kiedy to naturalistyczny pogląd na człowieczeństwo, inspirowany darwinizmem, zmagał się z neoromantycznym pragnieniem sensu, mocy i chwały. Podstawową dystynkcją w myśli Konińskiego było rozróżnienie na życie wartościowe i bezwartościowe. Pragnienie nadania wartości swemu życiu było dlań najważniejszym dążeniem człowieka, a perspektywa życia bezwartościowego budziła przerażenie. Zarówno dążenie do zbudowania w sobie wiary religijnej, jak i solidarność z własną wspólnotą narodową były dla Konińskiego różnymi aspektami dążenia do moralnej wyższości, podczas gdy perspektywa naturalistyczna budziła tylko przerażenie. Nietrudno wskazać myślicieli, którzy wpłynęli na Konińskiego, wśród swoich inspiracji wymieniał on Jeana Marie Guyau i Ottona Weiningera, spośród Polaków zaś Stanisława Brzozowskiego i Zygmunta Balickiego. Autorów tych łączyła problematyka uczynienia własnego indywidualnego życia wartościowym, co bezpośrednio wynikało z chęci przezwyciężenia nihilizmu. To ostatnie nie udało się Weiningerowi, który popełnił samobójstwo. Guyau, nim umarł na gruźlicę, poszukiwał etyki bez sankcji metafizycznej, w której dążenie do doskonałości byłoby aktem czystej jednostkowej woli. Balicki oddał się całkowicie we władanie idei narodu, podczas gdy Brzozowski nie dokończył swoich poszukiwań, zmagając się z marksizmem, nacjonalizmem i katolicyzmem. Istotnym punktem

\footnotetext{
88 K.L. Koniński, Zaufanie do rzeczywistości, s. 54.

Tenże, O wstrzas moralny, [w:] tenże, Zagadnienia religijne..., s. 107-109.
} 
odniesienia dla Konińskiego wydaje się także myśl Friedricha Nietzschego. Nie chcąc zawędrować tam, dokąd prowadził swych czytelników niemiecki myśliciel, Koniński dotarł w te rejony, które penetrowała myśl Simone Weil. Oboje w tym samym czasie, nie wiedząc o sobie wzajemnie, pisali w podobnym duchu. Ulegli idei szukania doskonałości poprzez posłuszeństwo chrześcijańskiemu Bogu, nawet jeśli nie byli pewni jego rzeczywistej obecności.

Problematyka życia wartościowego łączy się u Konińskiego z ideą narodową poprzez ideę udziału w wysiłku cywilizacyjnym, który zawsze dokonuje się w ramach wspólnoty narodowej. Inspiracją dla Konińskiego była tu lektura Brzozowskiego, Balickiego, a także innych twórców myśli wszechpolskiej: Romana Dmowskiego, Jana Ludwika Popławskiego i Zygmunta Wasilewskiego. W tym zakresie, w jakim myśl Narodowej Demokracji opisywała polskie interesy narodowe, wskazywała wrogów i przyjaciól, została ona zinternalizowana przez Konińskiego. Od przywódców obozu narodowego różnił go głównie dramatyzm w ujmowaniu polskiej roli dziejowej. Przejąwszy apologetyczną ideę Polski jako ośrodka wolności politycznej we wschodniej Europie, Koniński uznał, że misją Polski jest jej ratowanie. Dokonać tego mógłby tylko wielki naród, wielkość ta wymagała zaś wysiłków heroicznych. Można sądzić, że Koniński żądał od Polaków zbyt wiele. Nie tyle dlatego, że brakowało im wielkości ducha, ile przede wszystkim dlatego, że realizacja wielkich celów politycznych wymaga posiadania podstaw materialnych, które mogą zostać wytworzone jedynie w sferze gospodarczej. Stąd też idea narodowa Konińskiego prowadziła ostatecznie do wytworzenia neoromantycznej utopii woli. Gospodarcze podstawy potęgi politycznej miała zastępować wola i charakter.

\section{BIBLIOGRAFIA}

\section{Teksty źródłowe}

Koniński K.L., Boy, [w:] tenże, Pisma polityczne, oprac. i wstęp M. Urbanowski, Kraków 2014, Pisma Wybrane.

Koniński K.L., Budowa wiary. Traktat teologiczny, [w:] tenże, Zagadnienia religijne. Szkice, oprac. i wstęp Ł. Front, Kraków 2010, Pisma Wybrane.

Koniński K.L., Cesarstwo polskie, [w:] tenże, Pisma polityczne, oprac. i wstęp M. Urbanowski, Kraków 2014, Pisma Wybrane.

Koniński K.L., Cztowiek i naród, [w:] tenże, Kartki z brulionów, oprac. i wstęp B. Mamoń, Kraków 2007, Pisma Wybrane.

Koniński K.L., Cztowiek zupetny, twórca i naród (z powodu ksiażki Tagorego), [w:] tenże, Pisma polityczne, oprac. i wstęp M. Urbanowski, Kraków 2014, Pisma Wybrane.

Koniński K.L., Dialektyka nacjonalizmu (uwagi o książce Rene Johanneta), [w:] tenże, Pisma polityczne, oprac. i wstęp M. Urbanowski, Kraków 2014, Pisma Wybrane.

Koniński K.L., Dwie postaci konkretywizmu (patriotyzm liberalny i nacjonalistyczny), [w:] tenże, Pisma polityczne, oprac. i wstęp M. Urbanowski, Kraków 2014, Pisma Wybrane.

Koniński K.L., Ex labyrintho, Warszawa 1962. 
Koniński K.L., Karol Ludwik Koniński do Jerzego Turowicza, Odwaga i rzetelnośc, [w:] Przeciw antysemityzmowi 1936-2009, t. 1, red. A. Michnik, Kraków 2010.

Koniński K.L., Kilka truizmów w sprawie żydowskiej, „Gazeta Literacka” 1933, nr 10.

Koniński K.L., Listopad uniwersytecki (garść uwag), [w:] tenże, Pisma polityczne, oprac. i wstęp M. Urbanowski, Kraków 2014, Pisma Wybrane.

Koniński K.L., Logika swastyki, „Przegląd Powszechny” 1933, t. 197.

Koniński K.L., Na tropach frazesu, [w:] tenże, Pisma polityczne, oprac. i wstęp M. Urbanowski, Kraków 2014, Pisma Wybrane.

Koniński K.L., Nacjonalizm, religia, wolność. Obyczaj i myśl, [w:] tenże, Zagadnienia religijne. Szkice, oprac. i wstęp Ł. Front, Kraków 2010, Pisma Wybrane.

Koniński K.L., Nox atra, Warszawa 1961.

Koniński K.L., O cztowieku polskim. Na jubileusz Ignacego Chrzanowskiego, [w:] tenże, Pisma polityczne, oprac. i wstęp M. Urbanowski, Kraków 2014, Pisma Wybrane.

Koniński K.L., O wstrzas moralny, [w:] tenże, Zagadnienia religijne. Szkice, oprac. i wstęp Ł. Front, Kraków 2010, Pisma Wybrane.

Koniński K.L., Obyczaj i myśl, [w:] tenże, Pisma polityczne, oprac. i wstęp M. Urbanowski, Kraków 2014, Pisma Wybrane.

Koniński K.L., Struktura i symbol narodu, [w:] tenże, Pisma polityczne, oprac. i wstęp M. Urbanowski, Kraków 2014, Pisma Wybrane.

Koniński K.L., Szkice krytyczne. Wybór, oprac. i wstęp A. Fitas, Kraków 2007, Pisma Wybrane.

Koniński K.L., Taniec dialektyczny, czyli o humanizmie z zastrzeżeniami, [w:] tenże, Pisma polityczne, oprac. i wstęp M. Urbanowski, Kraków 2014, Pisma Wybrane.

Koniński K.L., Uwagi 1940-1942, oprac. B. Mamoń, Poznań 1987.

Koniński K.L., W sprawie Ch. O. S. (O wspótczesnej sytuacji religijnej), [w:] tenże, Zagadnienia religijne. Szkice, oprac. i wstęp Ł. Front, Kraków 2010, Pisma Wybrane.

Koniński K.L., Zaufanie do rzeczywistości, [w:] tenże, Zagadnienia religijne. Szkice, oprac. i wstęp Ł. Front, Kraków 2010, Pisma Wybrane.

\section{Literatura}

Bergmann O., Narodowa Demokracja wobec problematyki żydowskiej w latach 1918-1929, Poznań 1998.

Chołoniewski A., Duch dziejów Polski, Kraków 1918.

Clark C., The Conditions of Economic Progress, London 1957.

Dawidowicz A., Zygmunt Balicki (1858-1916). Dziatacz i teoretyk polskiego nacjonalizmu, Kraków 2006.

Dmowski R., Myśli nowoczesnego Polaka, Lwów 1907.

Dmowski R., Separatyzm Żydów i jego źródta, Warszawa 1909, Kwestia Żydowska, 1.

Fitas A., Gtos z labiryntu. O pismach Karola Ludwika Konińskiego, Wrocław 2003, Monografie

Fundacji na Rzecz Nauki Polskiej. Seria Humanistyczna.

Front Ł., Myśl religijna polskiego modernizmu i jej konteksty (Karol Ludwik Koniński), Kraków 2014, Biblioteka Tradycji. Seria 2, 135.

Grott B., Zygmunt Balicki. Ideolog Narodowej Demokracji, Kraków 1995. 
Grzybek D., Polityczne konsekwencje idei ekonomicznych w myśli polskiej 1869-1939, Kraków 2012, Societas, 32.

Guyau J.M., Zarys moralności bez powinności i sankcji, Warszawa 1960.

Jezierski A., Leszczyńska C., Historia gospodarcza Polski, Warszawa 1997.

Kalbarczyk A., U podstaw krytyki. O aksjologii literackiej Karola Ludwika Konińskiego, Lublin 2001.

Kulak T., Jan Ludwik Poptawski - biografia polityczna, Wrocław 1994.

Łętocha Ł., Socjalizm chrześcijański Karola Ludwika Konińskiego, [w:] tenże, O dobro wspólne. Szkice z katolicyzmu spotecznego, Krakow 2010.

Maj E., Związek Ludowo-Narodowy 1919-1928. Studium z dziejów myśli politycznej, Lublin 2000.

Mamoń B., Karol Ludwik Koniński, Kraków 1969, Ludzie i Czasy, 6.

Maternicki J., Idee i postawy. Historia i historycy polscy 1914-1918. Studium historiograficzne, Warszawa 1975.

Mencwel A., Etos lewicy. Esej o narodzinach kulturalizmu polskiego, Warszawa 1990.

Mencwel A., Stanistaw Brzozowski. Postawa krytyczna. Wiek XX, Warszawa 2014, Seria Historyczna Wydawnictwa Krytyki Politycznej, 17.

Mich W., Obcy w polskim domu. Nacjonalistyczne koncepcje rozwiązania problemu mniejszości narodowych 1918-1939, Lublin 1994.

Prokop-Janiec E., Literatura i nacjonalizm. Twórczość krytyczna Zygmunta Wasilewskiego, Kraków 2004, Modernizm w Polsce, 1.

Rybarski R., Naród, jednostka i klasa, Warszawa 1926.

Sikorski T., Nacjonalizm humanistyczny - czyli patriotyzm wolny od uprzedzeń w pisarstwie politycznym i krytyce literackiej Karola Ludwika Konińskiego (1891-1943), [w:] Narodowa demokracja XIX-XXI wiek. Dzieje ruchu politycznego, t. 1: Koncepcje - ludzie, red. T. Sikorski, A. Wątor, Toruń 2012.

Sobczak M., Narodowa Demokracja wobec kwestii żydowskiej na ziemiach polskich przed I wojna światowa, Wrocław 2007.

Sobczak M., Stosunek Narodowej Demokracji do kwestii żydowskiej w Polsce w latach 1918-1939, Wrocław 1998, Prace Naukowe Akademii Ekonomicznej im. Oskara Langego we Wroctawiu, 796. Monografie i Opracowania, 124.

Tomaszewski J., Landau Z., Polska w Europie i świecie 1918-1939, Warszawa 2005.

Uliński M., Kobieta i mężczyzna. Dzieje refleksji filozoficzno-spotecznej, Kraków 2001,

Urbanowski M., Nacjonalistyczna krytyka literacka. Próba rekonstrukcji i opisu nurtu w II Rzeczypospolitej, Kraków 1996.

Walicki A., Polska, Rosja, marksizm. Studia z dziejów marksizmu i jego recepcji, Warszawa 1983, Biblioteka Studiów nad Marksizmem, 24.

Walicki A., Stanistaw Brzozowski - drogi myśli, Warszawa 1977.

Wapiński R., Narodowa Demokracja 1893-1939. Ze studiów nad dziejami myśli nacjonalistycznej, Wrocław 1980.

Wapiński R., Roman Dmowski, Lublin 1988.

Weil S., Wybór pism, przeł. i oprac. Cz. Miłosz, Kraków 1991. 
Weininger O., Pteć i charakter, przeł. O. Ortwin, Warszawa 1994.

Wierzbicki A., Wokót Ducha dziejów Polski. Spory o ocenę dziejów narodowych w historiografii polskiej 1917-1919, „Kwartalnik Historyczny” 1971, R. 78, nr 4.

Wyka K., Koniński Karol Ludwik, [w:] Polski stownik biograficzny, t. 13, Wrocław-Warszawa 1967-1968.

Dr hab. Dariusz GRZYBEK (ur. 1970) - historyk i politolog, pracownik Wydziału Zarządzania i Komunikacji Społecznej Uniwersytetu Jagiellońskiego, ostatnio wydał Handel i pokój. Geneza i ewolucja liberalnego pacyfizmu, Kraków 2015. 